Arhe XVIII, 35/2021

UDK 1 Gramsci A.

$141.82: 2$

DOI https://doi.org/10.19090/arhe.2021.35.241-259

Originalni naučni rad

Original Scientific Article

ORAZIO MARIA GNERRE ${ }^{1}$

University of Perugia, Italy

\title{
MARXISM AND RELIGION: \\ A JOURNEY WITH GRAMSCI
}

\begin{abstract}
The relationship between Marxism and religion has often been taken for granted. In fact, history shows how these areas have never been completely isolated and, at times, they have come together. In this article we will reflect on this relationship through some elements of primary importance in the discourse of Antonio Gramsci, as a theorist of the philosophy of praxis. We will compare some elements of the Sardinian author's thought with that of three protagonists of Catholic philosophical and political thought from as many different backgrounds: Joseph De Maistre, for the conservative sphere; Gilbert Keith Chesterton, for the RepublicanDemocrat; James Connolly, for the Communist one.
\end{abstract}

Keywords: Religion, Marxism, Philosophy of praxis, Catholicism, Antonio Gramsci, Joseph De Maistre, Gilbert Keith Chesterton, James Connolly

\section{AN OPEN QUESTION}

There is a 1977 Soviet film, The Ascent (Voshkozhdeniye), by the Ukrainian-born director Larisa Shepit'ko, which is very interesting as a food for thought for a discourse on Marxism and religion. This film, produced, shot and distributed in the middle of the Brezhnevian era, presents a very particular sensitivity towards religious issues, in front of which the Western public could be quite surprised. We can in fact say that, in this film, there are three levels of treatment of the religious question: one symbolic, one political, and one (in negative, on the reverse) on atheism.

\footnotetext{
${ }^{1}$ Author's e-mail address: oraziomaria.gnerre@studenti.unipg.it
} 
The plot of the film in question takes place during the Second World War, and the protagonists are a group of Soviet partisans who fight against the German enemy, which has penetrated widely into the territory of the motherland. The whole symbolic representation of the feature film is grafted onto this story: one of the two protagonists, the younger, animated by the patriotic spirit and faithfulness to the principles of equality and solidarity of the Bolshevik revolution (represented in one of the final moments by a child with the typical budënovka hat of the Leninist militiamen, in a scene of strong impact), sacrifices himself by allowing himself to be "martyred" by the Nazis and their collaborators, in order not to betray the values in which he believes. The development of these events is constructed in such a way as to signify the Christic Via Crucis quite clearly for the viewer. To this is added that the other protagonist, an older soldier, betraying his cause, is configured almost explicitly as the double of Judas Iscariot, up to the attempted suicide operated out of guilt, just as happens in the Christian tradition for the renegade apostle.

Not only a symbolic level, we were saying, but also a political one: one of the characters the protagonists encounter is an Orthodox priest. If in the beginning he generates a certain degree of distrust among the partisans, skeptical of the real political positions of the Church, finally the pope in question proves to be pervaded by the same patriotic spirit as the protagonist, and assists the cause of the combatants.

The passage on the question of atheism, then, is truly singular: in one scene, a collaborator of the Nazis of Slavic origin confesses the reasons why he adhered to the ideology of the Germans. Specifically, he argues that by not believing the Nazis in God, they are allowed everything, even the violation of every moral norm. The echoes of a very simplified Nietszche are obvious in this speech.

First of all, it must be said that this film is typical of the cultural climate that reigned during Brezhnev's presidency. Brezhnevism, which wanted to recover those cultural and social elements considered positive of the era of Stalinism, on the one hand exalted all the national-patriotic aspects that developed during the Second World War (precisely, the Great Patriotic 
War), from the other consolidated close relations with the Orthodox $\mathrm{Church}^{2}$, precisely in the wake of what happened decades earlier thanks to the famous Georgian revolutionary ${ }^{3}$.

But if it is true that the relations between the Soviet state and the Orthodox Church were always ambivalent and always subjected to reversals during the years of Soviet power, this highlights how the communist perspective towards religions (both organized and not) has not always been univocal. Of course, there are a series of elements that assist the taking of easy positions in this regard, allowing us to believe that we can exhaust the question with some very generalist concept, as with the famous Marxian affirmation on religion as the opium of peoples, a definition which, as it has sometimes been pointed out that it is by no means the last word on Marxism and religion.

With this article we want to investigate, through Gramsci, another possible interpretation of the religious phenomenon within the Marxist school of thought, aware of two things: the first is that Marxism, proposing itself as a science, is comparable to its theorists with empirical data and open to new evaluations, if corroborated by facts. This is perhaps not frequent among contemporary Marxists, who often fall back on dogmatic formulas and unshakeable certainties, but this does not detract from the premise we have set out; the second is precisely that, in history, Marxist thinkers have anticipated this type of reflection on the role of religion within a dialectical materialist perspective. In this sense, we repeat, the role of Gramsci's thought can be of great help in opening up a conceptual path in this topic.

The exemplary case of Šepit'ko's film serves precisely as estranging information with respect to an almost monolithic narrative, in the West espoused by both communists and non-communists, so that no reconciliation is possible between Marxism and religion.

For a Western observer it is difficult to understand how the Soviet Union could have sponsored the recovery of Orthodox Christian symbolism

${ }^{2}$ Cfr. Giovanni Codevilla, Chiesa e impero in Russia. Dalla Rus' di Kiev alla Federazione Russa, Jaca Book, Milan 2011.

${ }^{3}$ Cfr. Adriano Roccucci, Stalin e il patriarca: Chiesa ortodossa e potere sovietico, 1917-1958, Einaudi, Turin 2011. 
for its own cinematography. At the most, these things are usually justified with the Russian national unconscious, founded on the myth of transcendent salvation and collective sacrifice, the national unconscious that would reproduce in a completely spontaneous and non-voluntary way. But, as we have seen, this is not the case. It is also difficult to imagine such a promotion of the alliance between the Church and the socialist state, with the full awareness, expressed by the film, that the Church continues to maintain its own vision of the world and of partially autonomous politics, not subordinated to a purely social level, neither to the secular authorities. Finally, it is truly unusual that, in a film of this kind, it is the Nazi who makes a profession of atheism, so as to connect the latter to modern nihilism, in which every moral reference and every trace of humanism vanishes.

As we shall see, the case is therefore far from closed.

\section{AGNOSTICISM AND RELIGION}

Again in the negative, we outline the question of religion with respect to another variant contrary to it, agnosticism. It is very interesting to know how the concept of agnosticism for Antonio Gramsci had a fundamentally negative value, to the point of being used extensively to describe a certain attitude of the human being towards reality and thought.

Let us take for example a passage by Gramsci in defense of the autonomy of the philosophy of praxis where this term is used. In criticism of Otto Bauer's theses, which suggested that in parties that referred to the philosophy of praxis, it was necessary to bring together a plurality of philosophies of life, religions and spirituality, all understood as the basis of this fundamental theory of Marxist derivation, Gramsci argues instead its autonomy and therefore revolutionary nature. With words that recall the Gospel passage of "I did not come to bring peace, but the sword" ${ }^{4}$, Gramsci notes that "a theory is precisely" revolutionary "insofar as it is an element of separation and conscious distinction in two fields ${ }^{5 "}$. Denying the principle of autonomy and the revolutionary nature of the philosophy of praxis would

\footnotetext{
${ }^{4}$ Mt 10, 34.

${ }^{5}$ Notebooks from the Prison 11, 27.
} 
mean, for Gramsci, proposing an "agnosticism [which is] the most vile and abject opportunism ${ }^{6 "}$.

Again by the Sardinian thinker, the "agnosticism" of the literary opinions of the italian philosopher Adelchi Baratono was considered "nothing other than moral and civil cowardice ${ }^{7 "}$.

Again against agnosticism, in a passage from the Notebooks on Esperanto, he has a way of opposing the fact that "every form of thought must consider itself as" exact "and" true "and fight other forms of thought ${ }^{8 "}$.

Instead, it is in his 25 years that Gramsci expresses himself for the first time in a decisive way on religion, from the pages of Avanti!, the famous italian socialist newspaper. He writes how "religion is a need of the spirit. Men often feel so lost in the vastness of the world, they feel so often tossed about by forces they do not know, the complex of historical energies so refined and subtle escapes common sense so much that in the supreme moments only those who have replaced religion with some other moral strength manages to save itself from collapse" will only be refined, without structurally changing.

What this represents within the thought of the Sardinian theorist is to be understood, on the basis of the lesson of Hegelian philosophy, as the consideration of religion as an "initial" factor of knowledge, or rather of understanding the world in its totality. On the contrary, religion would be precisely the fundamental modality of knowledge, with which man approaches (as the same passage just reported) to problems that are difficult to summarize, and which need a symbolic mediation so as to become explicable and better approachable .

He wrote in the Notebooks: "the main elements of common sense are provided by religions and therefore the relationship between common sense and religion is much more intimate than between common sense and the philosophical systems of intellectuals ${ }^{10 "}$. It is well known that for Gramsci

\footnotetext{
${ }^{6} I v i$.

${ }^{7}$ Notebooks from the Prison 1, 96.

${ }^{8}$ Notebooks from the Prison 11, 45.

${ }^{9}$ Antonio Gramsci, Stregoneria, on Avanti!, $4^{\text {th }}$ May 1916.

${ }^{10}$ Notebooks from the Prison 11, 13.
} 
these elements, as well as in religion, were built and refined in every form of popular culture, as well as in traditional stories, which in the figure of the Grimm brothers, for example, represented part of the German nationalpopular culture ${ }^{11}$. This was to understand how a certain pre-modern culture was of great interest to Antonio Gramsci, who highlighted its historical role in the formation of the conscience of the people.

This ability of religion to provide a framework in which to be able to insert the elements of reality, allowing a greater understanding, is what makes it different from that agnostic spirit that was so disliked by Gramsci. If religion (and the premodern mythical thought with it) offered its bearers a set of certainties, to be understood also as points of support through which to operate on the real, it becomes evident how agnosticism comes to correspond, without any doubt, with that fundamental indolence of which Gramsci accused what he proverbially called "indifferents".

Certainly Gramsci was not aware of it, but this perhaps little investigated element of his thought is very similar to that of a classical author of political Catholicism, commonly ascribed to the "reactionary" school, Joseph De Maistre. This personality, famous for having opposed the French Revolution in life ${ }^{12}$, fled to Russia, where he was able to write his main work, The St Petersburg Dialogues ${ }^{13}$. This book, built as a three-voice dialogue, covers a whole series of themes, all aimed, however, at defining the fundamental soul of the concept of religion, understanding what is fundamentally against it. In this work De Maistre argued that the world is basically divided into theists and agnostics. The latter would be bearers of their own ontology and their own attitude towards the world: cowardly, they do not believe in the possibility of ideological confrontation or even in the radical transformation of the existing, all characteristics that De Maistre attributed solely to religion. This is for a substantial and fundamental reason, which is why only the hypothesis of a logical cause before all events can

\footnotetext{
${ }^{11}$ Cfr. Antonio Gramsci, I racconti dei fratelli Grimm. Le traduzioni originali dei «Quaderni dal carcere», Incontri Editrice, Sassuolo 2011.

${ }^{12}$ Indeed, even Gramsci was particularly critical of this historical event.

${ }^{13}$ Joseph De Maistre, St Petersburg Dialogues: Or Conversations on the Temporal Government of Providence, McGill-Queen's University Press, Montréal 1993.
} 
allow a rational orderability. This responds to the hardly contestable principle according to which only a general philosophy can allow a modification of the world in its social-relational sphere and of man in his ethical and behavioral aspect.

In fact, Gramsci too was the bearer of a "general philosophy", but in his case it was not the Catholic religion (to which he also paid particular attention, as we have seen), but the philosophy of praxis. To it, in the criticism of Bauer, he will also come to pay tribute to the need to preserve his orthodoxy ${ }^{14}$.

A scholar of De Maistre, shortly after him, the Spaniard Juan Donoso Cortés, would then write a text, the Essay on Catholicism, Liberalism and Socialism ${ }^{15}$. In the first half of the essay Cortés is faced with the theological and social problems posed to his political and religious faction by the socialists, and he comes to the conclusion that socialism is nothing more than an opposite and contrary religion to the Christian one, therefore a diabolical theology. In the second part, however, he confronts the liberal question, and writes how liberals (who are none other than the agnostics of De Maistre) completely escape any theological categorization, since they deeply detest any complete vision of the world, with which it is eventually It is possible to confront, both in a dialogical way and in the dialectical confrontation. Their guiding principle remains only that of the well-being and immutability of the universe, which cannot therefore be subsumed to an omega point, to a transcendent purpose, whether this is the Kingdom of God of Catholics or the sovereignty of the human being of socialists. In this sense, Cortés said, liberalism is absolute evil, since socialists represent the bearers of a theology, even if it is "satanic", liberalism on the other hand has no theology, and is opposed to any worldview of this type. The socialists would be only the reverse side of the Christians, the liberal agnostics would however be the irreducible enemy of the Christians and the socialists.

\footnotetext{
${ }^{14}$ Notebooks from the Prison 11, 27.

15 Juan Donoso Cortés, Essay on Catholicism, Liberalism and Socialism, Literary Licensing, Whitefish 2014.
} 
Through other philosophical paths, it was also what Gramsci thought about agnostics.

\section{RELIGION AND COMMUNISM}

It is well known the role that Lenin attributed to religion with the advent of the communist revolution. First of all, he believed that it should have changed from a public fact to a private affair. Secondly, he argued that with the development of socialism and the progressive realization of a fully communist society, it would progressively wither away ${ }^{16}$, just as the state structures, necessary only for the consolidation of class power, should have died out ${ }^{17}$. In addition to this, he was also a promoter of the so-called "militant materialism", a principle that provided for the theoretical struggle against superstition and religious beliefs ${ }^{18}$.

Nonetheless, it can be said that this represented his particular conclusions drawn from Marx's thinking on the matter, conclusions that were not necessarily shared by every proponent of scientific socialism.

In this regard, it is of great interest to investigate the opinion of another famous Catholic thinker, this time a follower of the political doctrine of Marx, the Irish trade unionist James Connolly, who was much admired by Lenin himself. The vision that he had of the religious question is well summarized by this passage from one of his articles from 1908:

"To the free-thinkers and rebels [...] God and the Church were nothing more than the schemes of a designing priesthood intent on enslaving and robbing the credulous masses. Religion was a systematised business of deception and trickery invented and perpetuated by men thoroughly aware of its falsehood and baseness, and consciously laying plans to maintain and spread it for their own selfish ends. Kings and rulers of all kinds were the creation of this crafty priesthood which used them to its own purposes. [...] That many otherwise excellent comrades have brought

\footnotetext{
${ }^{16}$ Lenin, Socialism and Religion, in Novaya Zhizn, 3 dicembre 1905.

${ }^{17}$ Cfr. Lenin, The State and Revolution, Penguin Books, London 1992.

${ }^{18}$ Lenin, On the significance of militant materialism, in Pod Znamenem Marksizma n. 3.
} 
such ideas over into the camp of socialism is also undeniable. But that they are also held by an even greater number of enemies of socialism is truer still. And it is in truth in the camp of the enemy such ideas belong, such doctrines are the legitimate children of the teachings of individualism, and their first progenitors both in England and France were also the first great exponents of the capitalist doctrines of free trade and free competition, free contract and free labour. Such conceptions of religion are entirely opposed to the modern doctrine that the intellectual conceptions of men are the product of their material conditions, and flow in the grooves channelled out by he economic environment.

In the light of this modern conception of the conditions of historical progress religion appears as the outcome of the efforts of mankind to interpret the workings of the forces of nature, and to translate its phenomena into the terms of a language which could be understood. The undeveloped mind cannot grasp an abstract proposition. Therefore that which the cultured man of the twentieth century would explain and understand as 'a natural process,' the mental vision of our forefathers could only see as the result of the good or ill will of some beneficent or evil spirit - some God or Devil.

Hence we had in Ireland in our Celtic legends a plentiful store of fairies, leprechauns and good and evil spirits, and every thing on land or sea, on wind or water that our fathers did not understand was readily attributed to the good or perverse genius of some member or members of this fairy host. In their turn the fairies were the descendants of the servants of the 'Unknown God' whom the Celt of old worshipped in his Druidic Groves. Anyone at all acquainted with the beliefs of the Irish peasant before the advent of the National School to 'spoil' him of his innocence is well aware chat his Catholicity was almost inextricably mingled with a belief in fairy lore and legend that testified that he was still in a transition state of mentality between belief in the spirits of Druidism and the angels of Catholicity.

He would have hotly repudiated such an insinuation. But to the seeing eye the proofs were palpable and undeniable, and this mental development of the Irish Celt towards a clearer conception of the universe, this progress, for it was a progress, from the conception of a world helplessly torn by the warring of spirits to the conception of a world ruled by a Creator holding a spirit world in subjection for a beneficent purpose, this 
development was paralleled throughout the earth by all the advanced races in their upward march to the conquest of truth. The point to be noted is this:

The different stages of development of the human mind in its attitude towards the forces of Nature created different priesthoods to interpret them, and the mental conceptions of mankind as interpreted by those priesthoods became, when systematised, Religion. Religions are simply expressions of the human conceptions of the natural world; these religions have created the priesthoods. Only he who stands upon the individualist conceptions of history can logically claim that priesthoods created religion. Modern historical science utterly rejects the idea as absurd.

Yet it is this utterly unhistorical idea, rejected by historical science as it is also rejected by the record of the countless thousands of priests of all religions who have cheerfully gone to martyrdom for their beliefs and martyrdom is incredible in a conscious imposter - it - it is this belief that is often brought in and made to do duty as a result of socialist thought by those who ought to know better. It is a matter for congratulation that Irish socialists are free of such excrescences on socialist belief." 19

As can be seen, Connolly's interpretation of the religious phenomenon was very similar - almost superimposable - to Gramsci's. Religion would be the method by which the people in history have built their own consciousness of the world, even according to Connolly more and more perfectly with the advancement of technology. If for Lenin the only plausible interpretation of religion turned out to be that of the false consciousness of the proletarian class, in the face of Connolly's thought it becomes clear that this is not its only possible understanding in the Marxist field.

Moreover, Connolly could well understand how a certain category, what he scornfully calls "free thinkers," used the critique of religion as a means of promoting individualism. Not only does the analogy with Gramscian agnostics become so very easy, but it is evident that, bringing to the necessary consequences the discourse of the Sardinian thinker and that of

19 James Connolly, Roman Catholicism and Socialism, on The Harp, September 1908. 
the Irish thinker, a purely anti-religious attitude is often to be understood as a pure demophobic demonstration.

There was, under the rule of the British Crown, a third Catholic author who should also be considered in this discussion. Unlike the previous ones, he was neither an exponent of monarchical legitimism nor of communism, but he called himself a republican ${ }^{20}$. Founder of the distributist movement, which demanded, as the name suggests, a redistribution of arable land and an economy based on small ownership, he supported radical democratic positions and opposed British imperialism in the world. A personal friend of the Fabians, and of Bernard Shaw in particular, he was in critical dialogue with the positions of the major socialist schools. It is very interesting to note that his critique of Bolshevism was by no means strictly political (on the other hand he probably had not read Marx, who in fact does not receive criticism in his work), but focused on the question of religion. $\mathrm{He}$, in particular, had to object to this passage from an article by Bukharin, which he draws from a US magazine, the Liberator:

"One of the tools for obscuring the conscience of the people is faith in God and the devil, good and evil spirits, saints, etc., in short, religion. The popular masses are addicted to faith in these things, yet, if we rationally address these beliefs, and try to understand where religion originates from and why it has the firm support of the bourgeoisie, we will understand clearly that today the function of religion is to act as a toxin, a toxin that has corrupted and continues to corrupt people's minds." 21

He mocked this correlation between bourgeoisie and religion, which he considered unfounded, thus responding to the ideas of the famous Bolshevik:

"If only we are sensible and reasonable we will know where religion originates from; and (which I think is particularly important) we will understand why the economic plutocracy, under whose rule we live, is pervaded by so much religious enthusiasm. We will understand why Lord

${ }^{20}$ Gilbert K. Chesterton, Il repubblicano tra le rovine, in Politica, NovaEuropa Edizioni, Milan 2017, pp. 121-128.

${ }^{21}$ Bukharin in Gilbert K. Chesterton, La vera accusa contro il bolscevismo, in Politica, NovaEuropa Edizioni, Milan 2017, pp. 115-116 [translated from Italian]. 
Devonport or Lord Beaverbrook are fighting for the Faith with the frenzy of Crusaders; why Mr. Andrew Carnegie focused on the theology of Greek patristics; and what is the cause of Mr. Selfridge's fanatical penances. We will no longer be perplexed by the encounter with processions of our wealthiest city traders who go on pilgrimage barefoot; the rather common vision of a stockbroker with a sackcloth will no longer be a reason for astonishment for us, not even momentary; in short, we will know the reason for that supernatural wave of conversions which everywhere coincided with capitalism, making all our millionaires mystics, and our modern capitalist society the most devout the world has ever seen." 22

Obviously, all these pious customs were not common among the prosperous bourgeois mentioned above, and this, according to Chesterton, invalidated Bukharin's theses. Not unlike Connolly, Chesterton believed that religion was not a mere factor of domination, but rather a way of thinking and "culturally being" of the people.

"Anyone who knows Europe or any part of it knows that religion is notoriously not a characteristic of the bourgeoisie, but rather of peasant culture. Indeed, the same author admits that the peasants are religious, while the proletarians are atheists, but, strange to say, he does not make a connection with the obvious fact that the former are free men, while the latter are wage slaves.

[...] We can easily answer Bukharin's solemn question about the origin of religion: if it is a fable, it is certainly a popular fable. If it does not come from God, it undoubtedly comes entirely from the people." 23

That the proletarian is, for Chesterton, the wage slave who in a regime of subordination does not have the keys to access that freedom that would allow him to create and produce culture again is a reason widely present in Marx's thought. For Marx, the proletariat should have formed its class consciousness, increasingly reconfiguring itself with the essence of the "people" until it dissolved in this state of total self-awareness all the

22 Gilbert K. Chesterton, La vera accusa contro il bolscevismo, in Politica, NovaEuropa Edizioni, Milan 2017, p. 116 [translated from the Italian].

${ }^{23}$ Ibidem, pp. 118-120 [translated from Italian]. 
subordination boundaries of society divided into classes, including that which would be inaugurated with the socialist dictatorship of the proletarians themselves over the bourgeoisie. It is in this process of self-awareness that the proletariat would probably have begun to regain its creative, "spiritual" prerogatives. In this sense, the link between freedom and self-awareness is very close, and as one increases, the other increases as well. With both, according to Marx, the expressive capacity, properly cultural, should also progress.

But what would happen if from what was the proletariat, once the slave chains that bound it to the harsh reality of human subordination to production processes were dissolved, a new religious culture arose? Without doubt this would be a contradiction of Leninist predictions, nevertheless this was the question on which, during the time of Brezhnev's presidency, in a period of maximum religious detente, Soviet academics focused ${ }^{24}$.

As we have said, Marxism envisages the re-evaluation of its premises on the basis of facts and the analysis of reality, in an attempt to stem any purely imaginary reading of the world. It would have been interesting to consider such a theoretical production, but events took their historical course with the collapse of the Soviet Union and that particular socialist experiment. History and theory go on.

\section{RELIGION AS A GNOSEOLOGICAL METHOD}

We talked about Chesterton for another reason as well. The English scholar was in fact known, read and appreciated by Antonio Gramsci. In a letter addressed to Tatiana Schucht, his sister-in-law, dated 6 October 1930, he expressed his opinion on the author in question, in relation to his main detective work, the adventures of the priest and investigator Father Brown, which Gramsci compared with the Sherlock Holmes by Sir Arthur Conan

\footnotetext{
24 "The Institute of Philosophy of the Academy of Sciences of the USSR in 1973 was reserved by the Central Committee of the party to elaborate the ideological alternatives to Bolshevism, including that of giving life to a new "symphony" between the nation and orthodoxy."

Giovanni Codevilla, Chiesa e impero in Russia. Dalla Rus' di Kiev alla Federazione Russa, Jaca Book, Milan 2011, pp. 538-539 [translated from Italian].
} 
Doyle. The question was obviously not confined to the mere literary sphere, but brought with it some important philosophical problems. Gramsci wrote:

"Chesterton wrote a very delicate caricature of detective stories rather than detective stories proper. Father Brown is a Catholic who makes fun of the mechanical way of thinking of Protestants and the book is basically an apology of the Roman Church against the Anglican Church. Sherlock Holmes is the Protestant policeman who finds the key to a criminal skein starting from the outside, based on science, on the experimental method, on induction. Father Brown is the Catholic priest who, through the refined psychological experiences given by the confession and the moral casuistry work of the fathers, without neglecting science and experience, but based especially on deduction and introspection, beats Sherlock Holmes in full, it makes him look like a pretentious boy, shows his narrowness and meanness. [...] Chesterton is a great artist, while Conan Doyle was a mediocre writer, even if made a baronet for literary merits; therefore in Chesterton there is a stylistic detachment between the content, the police intrigue and the form, therefore a subtle irony towards the subject matter that makes the stories tastier." 25

In this letter Gramsci perfectly grasped how Chesterton's intent, before being literary, was polemical, in this case against a certain way of thinking and understanding the reality towards which Gramsci was strongly critical. Through the medium of irony and the parody style, Chesterton attacked all the presuppositions of a certain type of mechanistic rationalism, typical of a society, the capitalist one, which would have forgotten the human factor in the social equation.

The stories of Father Brown, however, are not the only detective production of our author: to them we must certainly add the lesser known short stories of The Club of Queer Trades ${ }^{26}$, written previously, in 1905. Furthermore, the main theme of this book it is the same as in the stories of Father Brown, the clash between intuitive knowledge and deductive logic. The two positions are thus represented by the two Grant brothers, protagonists of the story together with the narrator. Rupert, the de facto

${ }^{25}$ Quoted in Antonio Gramsci, Sherlock Holmes \& Padre Brown. Note sul romanzo poliziesco, Marietti, Bologna 2019 [translated from Italian].

${ }^{26}$ Gilbert K. Chesterton, Il club dei mestieri stravaganti, Lindau, Turin 2018. 
investigator, is a caricature of Sherlock Homles, who should solve cases with iron logic, but cannot; Basil, on the other hand, a former judge by now completely mad, whose madness is actually an attempt to escape the stringent laws of reasoning imposed within his own society and which he no longer shares, succeeds through intuitive abilities to arrive earlier and better to the solution of the puzzles.

Once again, two theories of knowledge emerge, opposed to each other. Chesterton has Judge Grant, engaged in debate, say:

"The simple facts! Do you really think... are you so imbued with superstition, so attached to those dark prehistoric beliefs that he believes in the facts? Don't trust immediate impressions? [...] What is the whole world based on, if not immediate impressions? What's more concrete? Dear friend, the philosophy of this world may well be based on facts, but its development is all a matter of spiritual intuitions and atmospheres. Why do you decide to hire an employee or not? Is his skull measured? Do you learn his mental health from a book? Is it really based on facts? No way. We hire an employee who believes himself capable of saving the company ... and discards one who is feared will steal the proceeds, only and only by virtue of certain mysterious impressions, on the basis of which I affirm, with absolute certainty and in all honesty, that that man, there in the street next door, is a first-rate impostor and rogue." 27

If the "philosophy of this world" is based on facts, mere facts for Chesterton were not representative of anything if separated from a philosophical dimension based on a cardinal principle, a worldview, a real origin of knowledge. Always Basil Grant, real voice of the author's thought, will have to say:

"The facts $[\ldots]$, how they obscure the truth, the facts. I may also be crazy - and in fact I'm out of my mind - but I never believed in that man ... what's his name? The one of sensational stories... Sherlock Holmes. Every detail refers to something else, without a doubt; but it usually points to the wrong thing. It seems to me that the facts point in all directions, like the thousand branches and twigs of a tree. Only the life of

${ }^{27}$ Ivi [translated from Italian]. 
the tree has meaning and unity, and rises towards the sky ... only the green sap that gushes like a fountain towards the stars." 28

Precisely this overall vision, witnessed by the image of the tree to which Chesterton refers, represents the foundation of knowledge. For Chesterton this cognitive modality is the operative principle of poetry (of which we speak in this book) and of religion (of which we speak instead in the short stories of Father Brown). Once again we have a correspondence of great importance with respect to Gramsci's thought: religion, as he maintained, would be above all a modality of knowledge, which holds together everything that escapes an immediate and quantitative understanding, but which nevertheless exists. it is and must be taken into account in some way.

But, if for Gramsci the philosophy of praxis would be a step ahead of premodern religions in terms of understanding reality, this does not change the fact that even the communist should not read reality in a purely quantitative sense. Despite Marx's economistic readings, it is quite clear how Marxism revolves around an axis of philosophical principles which are its fundamental pivot. Indeed, all the highly predictive "scientific" encrustations represent in Marxism perhaps a largely outdated historical element, if only because the increased multifactoriality of the events that take place before our eyes allows less and less a simplistically evolutionary reading of history. This clearly, as we said in the first passages of the text, should not exclude that empirical element which is so important in the philosophy of praxis, but should allow more space for experimentation than for pure prediction.

The problem posed towards the end of the Soviet political experiment returns: what should be the form of knowledge of a humanity finally freed from slavery to things, and master of its own collective future? Certainly, however much the scientific knowledge of humanity tends to increase, there will always be elements that will escape a simple explanation and that cannot be fully embraced with quantification. The expansion of knowledge, in fact, simply tends to shift the localization of the boundaries of

\footnotetext{
${ }^{28} I v i$ [translated from Italian].
} 
the unexplored. This was why Marx claimed we were still in prehistory, on the threshold of true history.

This pre-eminence of the qualitative factor over the purely quantitative one is also an element of supreme importance in Marxist reflection. The point of transmutation of the mere numerical aggregate into something that can represent a leap in level is precisely the central question of the theory of historical materialism, with the concepts of structure and superstructure. As Lenin already pointed out, and this is accentuated precisely in the Gramscian concept of hegemony, these two levels are not completely parallel, but tangle and influence each other in continuous historical reversals.

It is precisely in the theory of knowledge that Marxist philosophy and religious reality meet, beyond any merely historical, political and social factor. The epigones of the Marxist discourse actually began to reflect on religion often and willingly as a result of practical needs, but this has nevertheless led to the opening of some findings that still remain to be explored today. Findings that sound like Subcomandante Marcos's phrase, when he claimed to have entered the jungle with Marx's Capital, but to have learned to read the Popol Vuh there.

\section{BIBLIOGRAPHY}

Gilbert K. Chesterton, Il club dei mestieri stravaganti, Lindau, Turin 2018.

Gilbert K. Chesterton, Politica, NovaEuropa Edizioni, Milan 2017.

Giovanni Codevilla, Chiesa e impero in Russia. Dalla Rus' di Kiev alla Federazione Russa, Jaca Book, Milan 2011.

James Connolly, Roman Catholicism and Socialism, on The Harp, September 1908.

James Connolly, The Lost Writings, Edited by Aindrias Ó Cathasaigh, Pluto Press, London and Chicago 1997.

Juan Donoso Cortés, Essay on Catholicism, Liberalism and Socialism, Literary Licensing, Whitefish 2014.

Joseph De Maistre, St Petersburg Dialogues: Or Conversations on the Temporal Government of Providence, McGill-Queen's University Press, Montréal 1993.

Angelo D'Orsi, Gramsci. Una nuova biografia, Feltrinelli, Milan 2017.

Antonio Gramsci, I racconti dei fratelli Grimm. Le traduzioni originali dei «Quaderni dal cercere», Incontri Editrice, Sassuolo 2011. 
Antonio Gramsci, Quaderni dal carcere. Critical edition of the Gramsci Institute in four volumes, Einaudi 2014. Editore, Turin

Antonio Gramsci, Sherlock Holmes \& Padre Brown. Note sul romanzo poliziesco, Marietti, Bologna 2019.

Antonio Gramsci, Stregoneria, on Avanti!, $4^{\text {th }}$ May 1916.

Lenin, On the significance of militant materialism, in Pod Znamenem Marksizma n. 3.

Lenin, Socialism and Religion, in Novaya Zhizn, 3 dicembre 1905.

Lenin, The State and Revolution, Penguin Books, London 1992.

Austen Morgan, James Connolly: A political biography, Manchester University Press, Manchester 1988.

Donal Nevin, James Connolly, a Full Life: A biography of Ireland's renowned trade unionist and leader of the 1916 Easter Rising, Gill Books, Dublin 2005.

Adriano Roccucci, Stalin e il patriarca: Chiesa ortodossa e potere sovietico, 19171958, Einaudi, Turin 2011. 
ORACIO MARIJA NJERE

Univerzitet u Peruđi, Italija

\section{MARKSIZAM I RELIGIJA: PUTOVANJE S GRAMŠIJEM}

Sažetak: Odnos između marksizma i religije često se uzimao zdravo za gotovo. U stvari, istorija pokazuje kako ove oblasti nikada nisu bila potpuno izolovane, pa i da su se povremeno sastajale. U ovom radu reflektovaćemo taj odnos pomoću nekih elemenata koji su od primarnog značaja u diskursu Antonija Gramšija, kao teoretičara filozofije prakse. Uporedićemo neke elemente misli sardinijskog autora s onima trojice protagonista katoličke filozofske i političke misli sa isto toliko različitih zaleđa: Žozef de Mestr, za konzervativnu sferu; Gilbert Kit Česterton, za republikansko-demokratsku; Džejms Konoli, za onu komunističku.

Ključne reči: religija, marksizam, filozofija prakse, katolicizam, Antonio Gramši, Žozef de Mestr, Gilbert Kit Česterton, Džejms Konoli

Primljeno: 24.2.2021. Prihvaćeno: 4.5.2021. 
